\title{
Toward international understanding
}

By Ram Nandan P. Singh

Exchange of students between countries is as old as organized education itself. We are well aware of the extent to which students of the Roman Worlst frequented the schools of Athens and Alexandria. In ous own days international exchanges form an essential groundwork in creating cooperation between peo ples in different cultures of the globe. As a long term measure, they bring men and women as human beings face to face with each other. People no cloubt vary greatly in their thinking and acting, but the ultimate aspiration of every human breathing soul is the same. The exchange also confronts people with first hand experience with other cultures and establishes a link in communication which is so vital in creatimg better understanding.

Six countries of the world account for the greates number of foreign students enrolled. Population-wise this is as follows: U.S.A. 55,000: France 16,827 U.S.S.R 12,565: Argentinat 11,004: United Kingdom 10,443: and Federal Republic of Germany 9.643.

The University of Missouri with 270 enrolled from more than forty counnies has in tecent years helpecl bring the lecal community and student body together. The orientation pogram called Operatios: futer. national Frendship, organized in September, 1960. featured a reception for all new foreign students. It provided an opportunity to meet and talk with University officials, faculty and student leaders. On the following days there were lunchoons, more panel discussions, tours, and a picnic at the Cosmo Park sponsored by the Columbia Lions Club.

The preceding year witnessed remarkable programs in the field of incenational relations and it is worth noting some of these programs organized by the

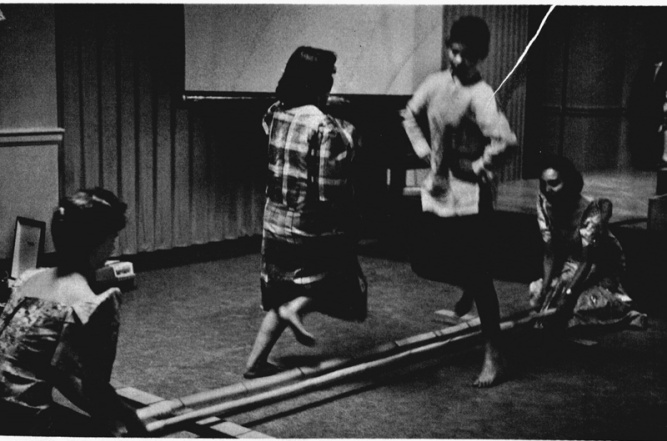

The "Tinikling Dence," from the Philippines, in which two bamboo poles are tapped together rhythrically as two girls dance in and out.

\section{5 / Missouri alumnus / MAY '61}




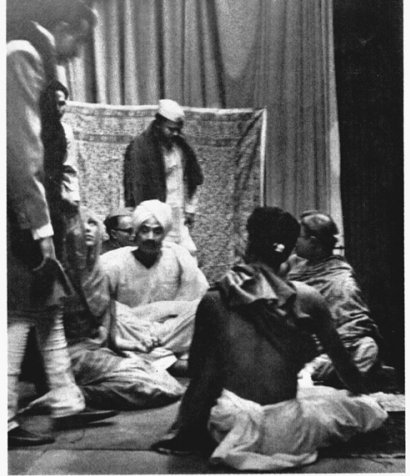

A scene from dramatic performance by Indian students portwying aedding customs

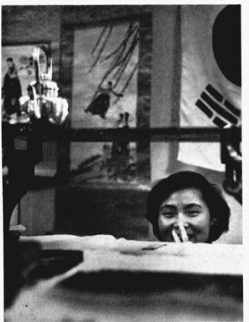

A shy Oriental smile for visitors to exhibits at Nations on Pande

\section{International cominuect}

University Cosmopolitan Club. This organization is a) University-recognied body, membership in which is open to all foreign students and interested American students

Nations on Parade: The program usually takes place during the spring semester and includes an international dress pageant and an exhibition of arts and crafts from various counuries. This all-day enter. taining program is eangerly awaited by the Columbians and local students.

Around the World in Sixty Minutes: A colorful and entertaining traveloguc program featuring dances, jokes and customs of various countries.

The Feast of Nations. Attended by about $3^{80}$ people, this international dinner was one of the most successful programs on the campus. The University YM-YWCA cooperated with the University Cosmopolitan Club members who prepared delicious dishes from twenty nations and served them at one dinner table. A variety show was presented. Dr. Elmer Ellis, our University president, was the guest speaker. 


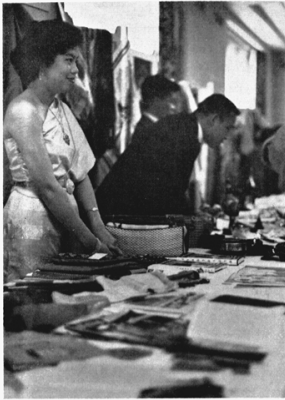

Arts and crafts from Thailand are anong the exhibils at popular Nations on Parade event.

The Embassy Whit: The International clubs of Stephens and Christian colleges cooperated with the University in putting on this "social night" which consisted of ballroom dancing and an international flou show.

Courship, Marriage and Lowe Around the World was a panel discussion organized by the University international organizations: the panelists brought out interesting ideas of prevailing customs in matrimony in different parts of the globe. Ideas That Moived the World featured short biographies of great men of the world, their belicfs and philosophies.

The president of the University holds a reception once a year in honor of all forcign students. In the past year, the Columbia Council of International Students, the University YM-YWCA and the Columbia Council of Church Women have made valuable conuibutions in this history-making process.

The frontiers of international relations have widened considerably in the last rwo years. A good example of one such process in action presently is the VM-YWCA International Seminar called "Acquaintance in Depth." The idea was initiated to confront these "non-official ambassadors" with oppor-

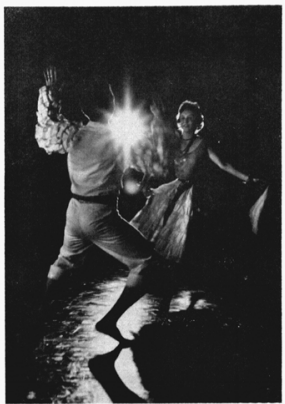

Studenis in Cuban daree at Latin American Exening organized by Eniversity Casmopolitan Club.

tunities so that there could be more than just casual acquaintance with their American counterparts. A serics of eight meetings were planned on stich topics as President Kennedy's Peace Corps, customs and superstitions, international games, etc. Four of the seminars have already been held.

As programs get oleler, new icleas and plans need to be brought in to sustain lively interest of our foreign visitors as also our own people. To studiv in a land other than one's own is an opportunity of fitr reaching consequences. At the same lime it brings in its trail problems never seen before.

The campus organizations who have fostered such activities are to be complimented for sharing with us their knowledge and skills. The writer is very optimistic that this operation in international understanding will expand to a dimension unoonceived so far, and with careful handling. will open up hori. zons toward better human resources throughout the globe.

Ran Nandan P. Simpli of Pama. India, is a tantidate for a Ph.D. degree in raral wrielngy at the liniversily. He has worked for the State Agriculiute Department in India. He was president of the Cosmopolitan Clab in igsertgen. 